\begin{tabular}{|c|c|c|c|}
\hline \multicolumn{4}{|c|}{ Ephemeris for Bertin Midnight. } \\
\hline $\mathbf{1 8 8 9}$ & $\begin{array}{l}\text { R.A. } \\
\text { h. m. s. }\end{array}$ & Decl. & Brightness. \\
\hline April I 8 & 5 IO 18 & I5 $30^{\circ} 6 \mathrm{~N}$ & 0.92 \\
\hline 122 & $\begin{array}{llll}\ldots & 5 & 8 & 57\end{array}$ & 15229 & 0.91 \\
\hline 26 & .. 5 & I5 I 5.2 & 0.91 \\
\hline 30 & $\begin{array}{llll}\ldots & 5 & 7 & 4\end{array}$ & $\ldots$ I5 $7.5 \mathrm{~N}$. & 0.90 \\
\hline
\end{tabular}

\section{ASTRONOMICAL PHENOMENA FOR THE WEEK 1889 APRIL $21-27$.}

( $F$ OR the reckoning of time the civil day, commencing at is here employed.)

\section{At Greenzevich on April 21}

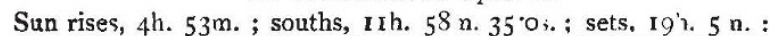
right asc. on meridian, $\mathrm{rh} .57^{\circ} 6 \mathrm{n}$; d decl. $12^{2} \mathrm{I}^{\prime} \mathrm{N}$. Jidereal Time at Sunsat, 9'. $5 \mathrm{~m}$.

Moon (at Last Quarter on April 22, 1 4h.) rises, Ih. Om. ;

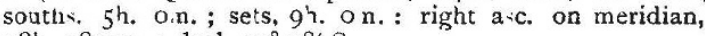
18h. $5^{8} \cdot 1 \mathrm{~m}$; d decl. $22^{\circ} 3^{\circ} \mathrm{S}$.

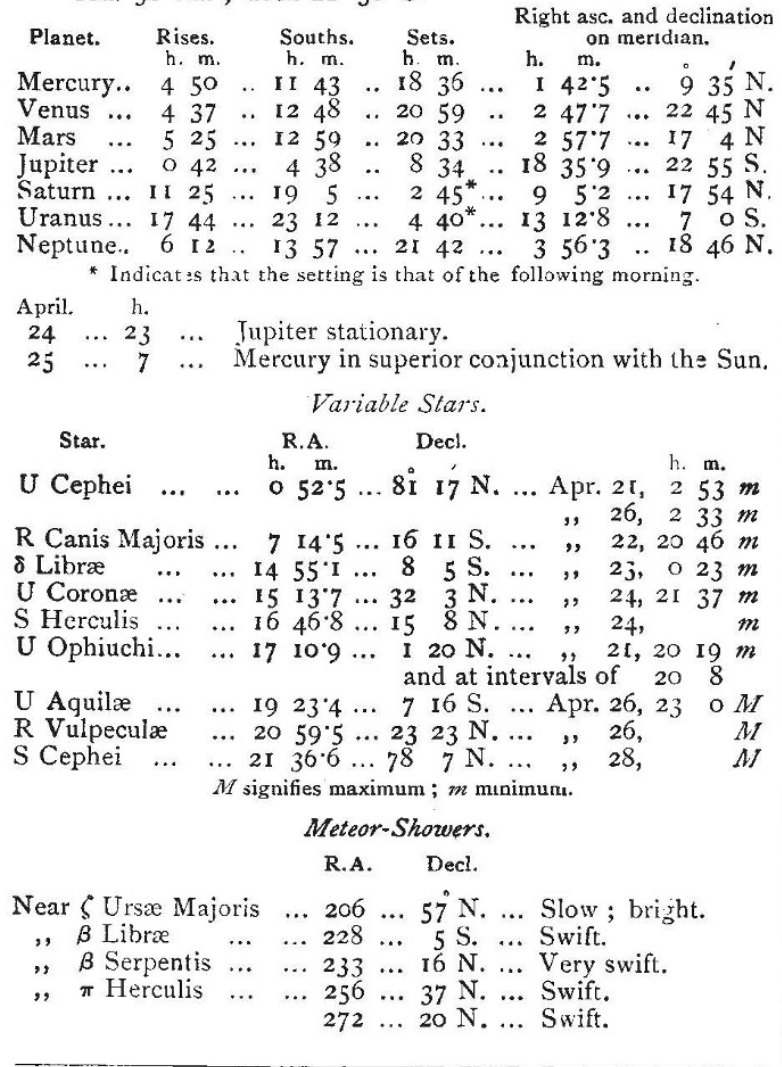

\section{GEOGRAPHICAL NOTES.}

To the current number of the Proceedings of the Royal Geographical Society, Mr. George Taylor contributes a valuable paper on Formosa and its aborigines. Mr. Taylor, while resident on the south coast of Formosa, had good opportunities of studying the natives, and the information which he has otherwise collected renders his paper the best summary of our knowledge of Formosa which we have at present. Mr. Taylor thus summarizes the geography of Formosa. On the western side, the land is composed of low level plains, extending from the sea-shore to some distance into the interior, the country appearing flat up to the more pronounced elevations which precede the steeper mountain slopes. The splendid watershed from the central mountains shows in the numerous rivilets which spreat like a network over the plains, and renders them especially suitable for the cultivation of rice and sugar-cane. The western sea-board partakes of the nature of the land, the coast being lined with mud and sand-sanks intersected by channels, this formation extending some distance out to sea. Within, Formosa is comparatively hilly, but large areas are covered with tea plantations, which form the principal industry. The east coast is rugged, precipitous, and exposed to the full fury of the north-east monsoon, which blows hard throughout eight months of the year; therefore, except in the Pilam plain and a few small valleys, little attempt is made at cultivation. To the soutb, the land terminates in huge masses of coral limestone, and coral branches may be traced in peaks elevated 2000 feet above sea-level. The sea-shore is lined with a semi-vitrified conglomeration of clay, sand, and coral, which presents a serrated surface so sharp and ragged as to be impassable to all beasts; and the natives, when fishing, are obliged to protect their feet with sandals composed of many folds of boar-skin. Mr. Taylor's account of the aborigines is specially valuable. While the pure aborigines from the interior are of an essentially Malayan type, stiil there is extraordinary diversity of features, indicating a considerable mixture of types. Among the Paiwang, probably the earliest settlers, head-hunting prevails. The Tipuns, again, seem to be of northern origin. To the naturalistwhether geologist, botanist, or zoologist-the interior of Formosa offers an almost virgin paradise.

Accounts are to hand of M. W. Delcommune's recent exploration of the Lomami, one of the most important southern tributaries of the Congo. Both Cameron and Wissmann met with the Lomami far to the south, and the latter conn sted it with the Sankuru. M. Delconmune, however, navigated the river from its mouth in the Congo, about 100 miles below Stanley Falls, for a distance of 580 miles, to a point only three days' journey from Nyangwé in the Lualaba. Tne river is reporied to traverse a magnificent country, to be free from all obstruction;, and to all appearance it continues to be navigable for some distance beyond M. Delcommune's farthest point.

Messrs. W. AND A. K. Johnston have sent us a copy of the third edition of their small map of Central Africa, in which $\mathrm{Mr}$. Stanley's recent route is laid down in red. The next edition ought to have the Lomami delineated in accordance. with M. Delcommune's recent explo:ation.

Africa fills a large place in the new number of Petermann's Mitteilungen. Dr. K. W. Schmidt has an article which deserves serious attention on the surface or soil conditions of German East Africa. Dr. Schmidt writes from careful personal observation, and his estimate of the capabilities of the German sphere is not very encouraging. Freiherr von Steinächer contributes some useful notes on German South-West Africa, with a map of Herreo Land and neighbouring regions. Dr. R. Luiddecke describes at some length the features of the new map of Africa, in six sheets, which has been prepared for the new edition of Stieler's " Hand-Atlas."

IN an interesting account in Les Missions Catholiques of a missionary's journey through Ecuador, it is stated that of the many towns and village, as Archidona, Canelos, \&c., the names of which appear on maps of the country, scarcely one exists. The natives do not live in villages, and even where there is a church, they live miles away in the forest in small solitary communities. Hitherto the missionaries have failed in inducing the natives to take to communal or social life.

M. Rogozinski, who has been in Europe for some time, has. returned to Fernando $\mathrm{Po}$, and intends to resume his explorations in the Cameroons region, and especially to endeavour to ascertain the existence or non-existence of the Lake Liba, which still figures mysteriously in maps of Africa.

THE death is announced of M. V. A. Malte-Brun, son of the great geographer of that name, and who himself for the last forty years had been a student of and writer on geo graphy.

\section{AFFORESTATION IN CHINA.}

THE question of afforestation in China is at the present time attracting a great deal of attention. China is a treeless country, and to this, perhaps, are due the devastating floods. which work such ruin there, and the fearful seasons of drought, which are almost as destructive as the floods. The timber used 
in various ways is all imported-chiefly from the Uniterl Stares of America, and fr im Hainan and F.rmosa. Till the overflow of the Vellow River some time ago, no one prid the least atten. tion to this question; bat now a proclamation of the liberal Viceroy, I,i Hung Chang, to the people of his thickly-populated provinces, shows that the subject will receive the attention it deserves. Hi, lixcellency says that one of the first principles in roverning a sinte is to watch over the agriculture of the State, s) that it may benefit both the inlividuals who till it and the State. In one of the provinces river which he rules-namely, that of Chihli-arboriculturt is rendered especially easy by the softness and fertility of its alluvial plains. If we omit the $\mathbf{v}$ rrio:ts species of fruit-trees, such as the apple, pear, and apricut, other kinds of trees are very rarely seen, and in con-equence vast tracts of ferile plains are left barren. Some slight attempts have been made to plant these extensive tracts with forest trees; but the strong northerly winds which prevail scon uprooted trees which had not been planted to a sufficient depth nor in wellchosen places. Amongst the peasants, the. Viceroy sayc, the principles of arboriculture are unknown, and therefore their previous efforts have only resulted in labour and money uselessly expended. In recent years the Viceroy has ordered the planting of willow-trees along the banks of the streams and rivers in Chihli, with the object of protecting and strengthening the embankments.

If success ul methods, His Excellency aska, have been found for cultivating trees in salt lands, how much more easy ought they to be found in the rich level plains of Chihli ? Accordingly, the authorities of the various prefectures and sub-prefectures of Chibli are instructed to procure the necessary seed trees, and to inform the people in their respective districts of the eight directions for tree-planting and the ten benefits to he derived from the same. Steps are to be taken by the authorities to encourage the people in their efforts at planting, but official agents, who might oppress the people, are not to be sunt among them. At the end of each year a statement is to be submitted to the authorities, by every person who has tried planting, of the number of trees he has receivel, the number successful, the species which have thriven best, \&c., s) that the Government may reward those who are most successful in these experiments in arboriculture, as well as gather information to guile them in the future. Instructions are given to the local anthorities to deal severely with any person who steals or cuts dow a the trees of others. The Vicerny says that his intentions in issuin 5 this proclamation are to afford another source of livelihond to the peasants, to help in preventing droughts and checking floods, to regulate the rainfall, and to beautify the country.

The eight directions and the ten benefits are worth recorling. The directions are as follow :- I) To fortify the roots againit injury from cold, which, on account of the loose nature of the soil near the surface, readily injures the roots, a fertilizer, mate by burning a mixture of dung and grass, should be used when planting trees, and when the fertilizer is put in, the roots should be carefuliy covered. (2) When a tree has bee I securely planted, a small cumulus of earth should be placed around it, 6 or 7 inches high, and should be renewed before winter sets in every year till the close of the third year. By this means the wind and cold cannot reach the roots, nor will the necessary natural nourishment in the earth escape. (3) In places exposed to high winds the trees should be p'anted to a depth of at least $3 \frac{1}{2}$ feet; at this depth the rich part of the soil is reached. In case of willows and other such trees, the outspreading and dependent branches are to be carefully pruned. (4) Rich earth, with a suitable fertilizer, is to be added to poorer soils. (5) To prepare the ground for the reception of the seeds of such trees as the oak, elm, popiar, cypress, \&c., which are shed every year, a trough is to be dug round each tree and filled with water to keep the soil moist. (6) Willow and mulberry trees shculd be planted in the spring, when there is rain. Before planting the young shoots, the soil should be well loosened and fertilized, and grafting should always take place after the rain, and the graft-trees should be well watered every alternate day. (7) In transplanting trees, the greatest care should be taken to preserve the three vertically-projecting roots, which every tree has, from the wind and sun. When there is rain, a small hole is to be dug by the side of the tree, cutting away one of these roots; this operation is to be repeated in a fortnight if there is rain; if not, a month must elapse before the second root is cut, and similarly in the case of the third root. When the roots are cut away, innumerable little roots will be thrown out. If there is no rain, the ground mist be well watered before any transplanting is attempted. (8) In raising trees fro $n$ the sceds of the oak, mulherry, \&.c., some fertile spot : hould be prepared just as it would be for a crop of grain, and the seeds are planted in the sime way as grain is planted. Spring time is the best, and while there is rain. When the young trees spring up and grow to the height of one or two feet, they can easily be transplanted as diracted above.

The ten benefits of planting trees are thus enumerated by His Exc-ilency :-(I) By planting trees at the river-banks the loose and sandy soil is strengthened by the roots, and the banks increase in height. (2) A large and profitable industry will spring up if pine, elm, willow, \&c., are planted in the mountains on the borders, (3) The planting of trees around fields and farms will do away with the superfluous moisture and preserve a fair equilibrium of wind and fluid influences. (4) Where trees are in abundance, droughts will be unknown. (5) A bundance of trees also help to ward off epidemics, and in thickly-populated district - trees should be specially planted for this purpose. (6) Where there is abundance of trees, travellers and families can find rest and shelter in the summer. (7) The operations of highwaymen and banditti are hindlered where trees and forests are plentiful. (8) The snows on the mountains of the border will he absorbed by forests. (9). The $p$ orer peasants will have sufficient fuel from the branches, which are pruned every year. (IO) Many of these trees, as the Ourrcus mongolica, afford food to the silkworm, which, in the mountainous regions, weaves a cocson which makes much cheaper and more durable siik than that of the mulberry silk-worm.

\section{SUPERSTITION AND SORCERY IN NEW $G U / N E A$.}

IN the Report to the Colonial Office of the Special Commissioner for British New Guinea during the past year, there is a long and very interesting account of some of the superstitions of the natives of that country, written by Mr. H. If. Romilly. One of the most sacred obligations, he says, on the relatives of a deceased man is to place in his grave, and in his accustomed haunts, food and water for the spirit of the departed. It is thought that this spirit is all that remains of the deceased, and the human appetites take possession of it, or, rather, remain in existence, just as if the body had not died. If, however, he is killed in bittle, there is not the same necessity of constantly feeding his spirit; the head of one of the tribe or race who killed him is sufficient. If the slayer is a white man, the angry spirit can be laid by a large payment of goods to the relatives of the deceased, and this constantly happens. Dreams are, to them, voices from the land of spirits, telling them what to do, for whom to work, from whom to steal, and what to plunder. White men are al "ays attended by a familiar spirit, which is blamed $f, r$ any mischief that befalls the natives in a locality where a white man happens to be. If the white man is a friend of theirs, they merely demand compensation, which he will pay, says Mr. Romilly, if he is a wise man; if he is unfriendly to them, the unfortunate white man may prepare for the worst. His attendant spirit will not help him, for it flies at the sound of a gun. On the death of a relative, there is a great drumming and burning of torches to send the spirit safely and pleasantly on its travels. In some parts of the country, certain trees have spirits, and on feast-clays a portion of the food is set apart for these spirits. It is worthy of remark that all their spirits are malignant, and these have to be overcome by force of arms, by blessings, or by cursings. They cannot grasp the idea of a beneficent spirit, but regard them all as resembling Papuans generally - that is, vindictive, cruel, and revengeful. Consequently, these spirits are much feared; though they cann t be seen, yet they constantly use arrows and spears when they are vexed. The great opposer of spirits is fire, and hence, on every possible occasion, bonfires and torches are employed. Strange to say, though fire is thus all-powerful with them, they have no god or spirit of the fire. In this they are at least true to their belief, for no spirit can be, with them, beneficent. Sorcerers are implicitly believed in, and they generally do a good trade in the sale of charms, which are made, not on any fixed principle, but according to the freaks of fancy of the sorcerer or the purchaser. Sometines it is a bit of bark, sometimes a crab's claw worled in the most fantastic way. These are protectors against all injuries or accidents that may happen to a 